\title{
Status Kualitas Air Sungai Ciliwung di Wilayah DKI Jakarta \\ Studi Kasus: Pemasangan Stasiun Online monitoring Kualitas Air \\ di Segmen Kelapa Dua - Masjid Istiqlal
}

\section{Water Quality Status of Ciliwung River in DKI Jakarta Region}

Case Study: Installation of Online Water Quality Monitoring Station

in Segment of Kelapa Dua - Istiqlal Mosque

\section{SATMOKO YUDO DAN NUSA IDAMAN SAID}

\author{
Pusat Teknologi Lingkungan, Badan Pengkajian dan Penerapan Teknologi
}

Gedung Geostech 820, Kawasan Puspiptek Serpong 15314, Indonesia satmoko.yudo@bppt.go.id

\begin{abstract}
Ciliwung River flows through the middle of Jakarta and many housing and densely populated. This causes the Ciliwung River to be heavily polluted from wastewater and solid waste. The purpose of this research is to know the water quality and water pollution load in Ciliwung river and to determine the location point of installation of water quality online monitoring station. The research method used is to analyze the quality of water samples taken from several points of the Ciliwung River. The result of the analysis shows that there is heavy pollution in several locations in Ciliwung river especially the area that go downstream of Ciliwung River. In addition, from the analysis results have been determined 8 (eight) points location plan placement unit online monitoring of water quality, because the limitations of the current fund only placed 3 (three) online monitoring units on site representing upstream, middle and downstream of the Ciliwung river.
\end{abstract}

Keywords: river water quality, pollution, water quality online monitoring

\begin{abstract}
ABSTRAK
Sungai Ciliwung merupakan sungai yang mengalir melalui tengah kota Jakarta dan melintasi banyak perumahan dan perkampungan padat. Hal ini menyebabkan kondisi sungai Ciliwung menjadi tercemar berat baik dari limbah cair maupun limbah padat. Tujuan dari penelitian ini adalah untuk mengetahui kualitas air dan beban pencemaran air yang ada di sungai Ciliwung serta untuk menentukan titik lokasi pemasangan stasiun online monitoring kualitas air. Metode penelitian yang digunakan adalah melakukan analisis terhadap hasil sampel kualitas air yang diambil dari beberapa titik di sungai Ciliwung. Hasil analisis menunjukkan bahwa telah terjadi pencemaran berat di beberapa lokasi di sungai Ciliwung khususnya daerah yang menuju hilir sungai Ciliwung. Selain itu dari hasil analisis telah ditentukan 8 (delapan) titik lokasi rencana penempatan unit online monitoring kualitas air, karena keterbatasan dana saat ini baru ditempatkan 3 (tiga) unit online monitoring di lokasi mewakili hulu, tengah dan hilir di sepanjang sungai Ciliwung.
\end{abstract}

Kata kunci: kualitas air sungai, pencemaran, online monitoring kualitas air 


\section{PENDAHULUAN}

\subsection{Latar Belakang}

Sungai sebagai salah satu komponen lingkungan yang memiliki fungsi penting bagi kehidupan manusia termasuk untuk menunjang pembangunan perekonomian. Sebagai akibat adanya peningkatan kegiatan pembangunan di berbagai bidang maka baik secara langsung ataupun tidak langsung akan mempunyai dampak terhadap kerusakan lingkungan termasuk didalamnya pencemaran sungai yang berasal dari limbah domestik maupun limbah non domestik seperti pabrik dan industri. Oleh karena itu pencemaran air sungai dan lingkungan sekitarnya perlu dikendalikan seiring dengan laju pembangunan agar fungsi sungai dapat dipertahankan kelestariannya ${ }^{(1)}$.

Terdapat 13 sistem aliran sungai yang mengalir di wilayah Provinsi DKI Jakarta yang sebagian besar berhulu di daerah Jawa Barat dan bermuara di Teluk Jakarta. Sungai-sungai tersebut merupakan tempat limpahan akhir dari buangan-buangan lingkungan sekitarnya. Padahal sungai itu sendiri mempunyai banyak fungsi yang sangat penting, antara lain sebagai sumber air baku air minum, perikanan, peternakan, pertanian, dan usaha perkotaan (1).

Dari hasil data pemantauan yang dilakukan Badan Pengendalian Lingkungan Hidup Daerah (BPLHD) pada 13 sungai yang melintasi wilayah Jakarta pada tahun 2010 menunjukkan, baik air sungai maupun air tanah memiliki kandungan pencemar organik dan anorganik tinggi. Akibatnya, air sungai diwilayah DKI Jakarta tidak sesuai lagi dengan baku mutu peruntukkannya yaitu air minum, perikanan, pertanian dan usaha perkotaan lainnya ${ }^{(2)}$.

Salah satu dari 13 sungai yang mengalir di Jakarta, yakni sungai Ciliwung memiliki dampak yang paling luas karena melewati tengah kota Jakarta dan melintasi banyak perkampungan, perumahan padat, dan pemukiman-pemukiman kumuh. Sampah dan limbah dari berbagai tempat dibuang di Sungai Ciliwung. Masalah ini terus bertambah besar ketika sampah-sampah yang ada menyumbat aliran air, mengakibatkan sungai berbau, kotor, dan yang paling menjadi momok warga Jakarta adalah terjadinya banjir( ${ }^{(3)}$.

Keadaan kualitas air Sungai Ciliwung saat ini dalam kondisi tercemar berat pada seluruh segmennya, mulai dari hulu (daerah Puncak, Kab. Bogor) sampai dengan hilir (di DKI Jakarta) ${ }^{(4)}$. Begitu juga fluktuasi debit air sungai antara musim kemarau dan musim hujan cukup tinggi, sehingga terjadi banjir rutin di hilir atau di wilayah DKI Jakarta.

Permasalahan utama yang terjadi di Sungai Ciliwung ada 2 hal, yakni :

1. Daerah konservasi yang semakin berkurang.
2. Beban pencemaran yang tinggi, baik dari limbah domestik maupun limbah industri.

Berdasarkan kondisi sungai Ciliwung yang telah disebutkan di atas, menunjukkan bahwa secara umum kondisi sungai di wilayah Jakarta sudah waktunya perlu perhatian yang sangat serius untuk dibenahi pemerintah bersama masyarakat. Usaha pemantauan kualitas air sungai secara berkala maupun secara online perlu terus selalu dilakukan dan usaha-usaha pemerintah bersama masyarakat baik itu penegakan hukum ataupun sosialisasi untuk meningkatkan kualitas lingkungan perairanpun perlu terus dilakukan. Sehingga diharapkan sungai sebagai sumber air bersih untuk kebutuhan hidup manusia yang utama tetap terjaga kualitasnya dan tidak semakin tercemar ${ }^{(2)}$.

\subsection{Gambaran Umum Sungai Ciliwung}

Daerah aliran sungai (DAS) Ciliwung memiliki fungsi sosial dan fungsi ekonomi. DAS Ciliwung yang melintasi wilayah Ibu Kota DKI Jakarta, adalah DAS urban yang memiliki arti strategis dalam konteks nasional yang perlu dikelola secara khusus. Panjang sungai Ciliwung dari bagian hulu sampai muara di pesisir pantai Teluk Jakarta adalah $\pm 117 \mathrm{~km}$, dengan luas DAS Ciliwung sekitar $347 \mathrm{~km}^{2}$. DAS Ciliwung mencangkup areal mulai dari bagian hulu di Tugu Puncak (Kabupaten Bogor) sampai hilir di Teluk Jakarta (Jakarta Utara) $)^{(4)}$.

Kegiatan pembangunan di DAS Ciliwung, baik di hulu maupun di hilir tergolong sangat intensif dan pertambahan penduduk cukup tinggi. Perubahan penggunaan lahan dan bertambahnya kawasan pemukiman di Ciliwung hulu, tengah dan hilir berimplikasi terhadap masuknya polutan ke DAS Ciliwung. Sumber pencemaran Sungai Ciliwung berasal dari limbah domestik, limbah industri, limbah pertanian, dan limbah peternakan ${ }^{(5)}$.

Sungai Ciliwung di dalam perjalanannya di wilayah DKI Jakarta menerima tambahan kapasitas dari saluran/sungai dan waduk baik dari segi kuantitas maupun kualitas. Saluran atau sungai yang masuk ke Sungai Ciliwung mulai dari Kelapa Dua, Depok sampai dengan pintu air Manggarai adalah :

1. Saluran Anak sungai JI. RA. Fadilah Cijantung.

2. Anak Sungai /Saluran Jl. Jembatan I yang merupakan Sub Das Tanjung Barat.

3. Sungai Condet yang banyak menampung air limbah domestik dan industri.

4. Saluran MT Haryono.

5. Saluran Tanjung Lengkong.

6. Saluran JI. Manggarai Utara IV.

Klasifikasi peruntukkan sungai atau badan air di Wilayah DKI Jakarta dapat dilihat pada Gambar 
1. Saluran atau anak sungai tersebut di atas merupakan saluran air hujan, air limbah domestik serta merupakan saluran pembuangan air limbah kegiatan komersial dan industri, sehingga sangat berpengaruh terhadap kualitas air sungai Ciliwung.

Peruntukan Sungai Ciliwung berdasarkan Keputusan Gubernur Propinsi DKI Jakarta No. 582 Tahun 1995 adalah sebagai sumber air baku air minum dengan klasifikasi Golongan $\mathrm{B}^{(6)}$. Dengan demikian seharusnya konsentrasi BOD air sungai Ciliwung tidak boleh melebihi $10 \mathrm{mg} / \mathrm{l}$ dan konsentrasi COD tidak boleh melebihi 20 $\mathrm{mg} / \mathrm{l}$.

Selain berfungsi sebagai sumber air baku air minum untuk kota jakarta, Sungai Ciliwung mempunyai fungsi sebagai sumber air penggelontor untuk daerah-daerah yang lebih rendah, yaitu daerah Cikini/Menteng dan daerah
Ciliwung Gajah Mada (Jakarta Kota). Penggelontoran dilakukan secara bergantian dengan melihat jumlah debit yang tersedia untuk penggelontoran.

Kewenangan pengelolaan sungai yang ada di wilayah DKI Jakarta berada pada kewenangan pemerintah pusat dan dan kewenangan Pemda DKI Jakarta. Pengelolaan sungai yang dikelola oleh pemerintah pusat yaitu Kali Angke, Sungai Pesanggrahan, Sungai Krukut, Sungai Ciliwung, Sungai Sunter, Sungai Buaran, Sungai Jati Kramat, Sungai Cakung. Sedangkan sungai yang pengelolaaannya di bawah kewenangan Pemda DKI Jakarta antara lain sungai Sekretaris, Sungai Grogol, Sungai Cideng, Sungai Kalibaru Timur, Sungai kalibaru barat dan sungai sungai lainnya. Secara garis besar pembagian kewenangan pengelolaan sungai sungai yang ada di wilayah DKI Jakarta(7) dapat dilihat pada Gambar 2.

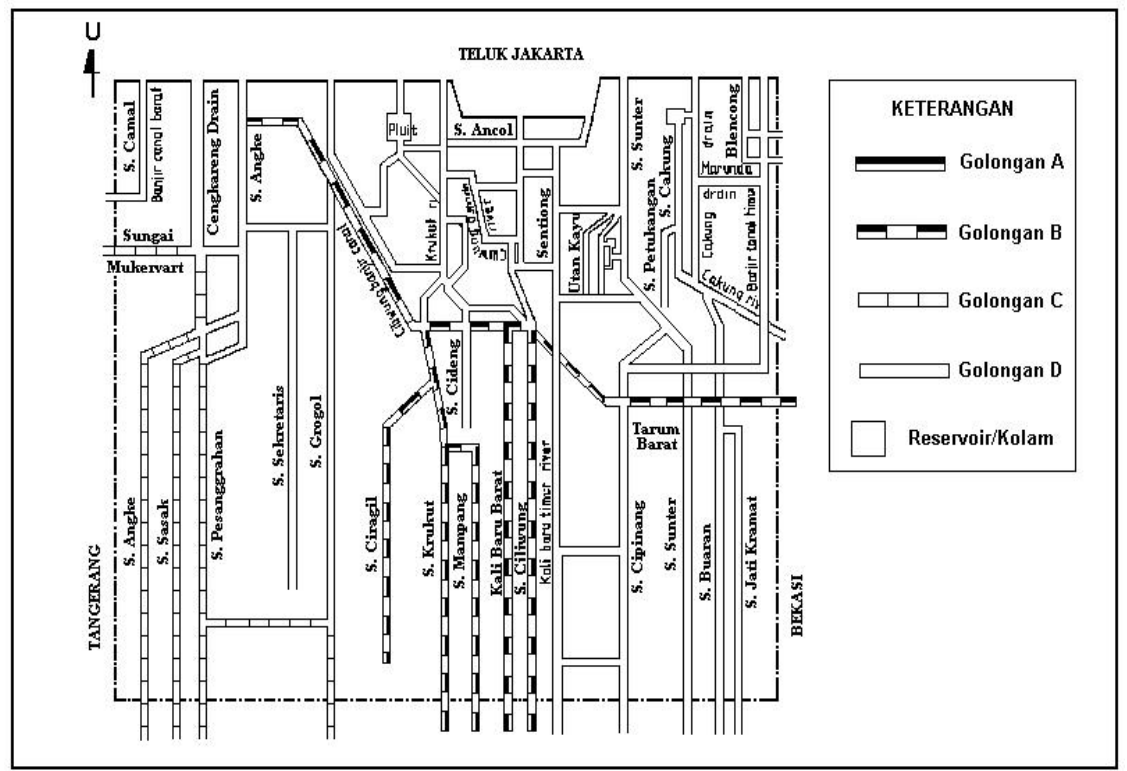

Gambar 1. Klasifikasi Peruntukan Sungai Atau Badan Air di Wilayah DKI Jakarta

\subsection{Tujuan}

Tujuan kegiatan ini adalah untuk mengetahui kondisi kualitas air sungai Ciliwung di beberapa lokasi mulai dari Kelapa Dua-Depok sampai dengan Masjid Istiqlal, serta untuk mengetahui kondisi kualitas air beberapa anak sungai yang masuk ke Sungai Ciliwung pada saat musim kemarau.

Sedangkan sasarannya adalah untuk menghitung beban pencemaran yang masuk sungai Ciliwung mulai dari Kelapa Dua-Depok sampai dengan Pintu Air Maggarai, dan beban pencemaran air sungai Ciliwung segmen Pintu Air Manggarai sampai Masjid Istiqlal pada saat musim kemarau. Dari hasil analisa kualitas air dan beban pencemaran tersebut akan ditentukan titik-titik lokasi rencana pemasangan unit online monitoring
(OnLimo) kualitas air di sepanjang sungai Ciliwung, segmen Kelapa Dua, Depok - Masjid Istiqlal.

Sistem kerja teknologi OnLimo adalah memantau kualitas air dengan menggunakan unit sensor yang terintegrasi dengan unit data logger, unit transmisi data dan sistem software. Teknologi ini dapat diterapkan untuk pemantauan kualitas air baik di sungai, danau, waduk, pantai maupun di perairan laut serta memantau kualitas air limbah di industri. Sensor yang digunakan dapat memantau 12 parameter (Temp, Conductivity, Salinity, TDS, DO, pH, Turbidity, Depth, Amonia, Nitrat, ORP, $C O D)$. Selain itu disediakan slot data untuk parameter lain seperti untuk mengukur debit, curah hujan dan tinggi muka air ${ }^{(8)}$.

Sampai saat ini telah dibangun 3 unit Online monitoring kualitas air sungai Ciliwung ${ }^{(9)}$ yaitu di : 
1. Srengseng Sawah, Kel. Srengseng, Kec. Jagakarsa. (Kelapa Dua-Depok); Mewakili daerah hulu sungai Ciliwung.

2. Pintu Air Manggarai, Kel. Pegangsaan, Kec. Menteng; Mewakili daerah tengah sungai Ciliwung. dan

3. Jembatan Masjid Istiqlal, Kel. Kebon Kelapa, Kec. Gambir; mewakili daerah hilir sungai Ciliwung.

\section{BAHAN DAN METODE}

\subsection{Tempat dan Waktu}

Lokasi penelitian disepanjang sungai Ciliwung mulai dari Kelapa Dua-Depok mewakili daerah hulu sampai di Masjid Istiqlal-Jakarta Pusat mewakili daerah hilir. Pengambilan sampel dan pengukuran parameter air dilaksanakan pada tanggal 4 dan 5 November 2014 dari pukul 09.00 s.d. pukul 16.30 WIB. Pengambilan contoh air dilakukan di 9 (sembilan) lokasi yaitu 7 (tujuh) sampel di sungai Ciliwung dan 2 (dua) sampel di saluran atau anak sungai Ciliwung. Titik lokasi pengambilan sampel dapat dilihat pada Tabel 1.

\subsection{Bahan dan Peralatan}

Peralatan dan bahan yang digunakan dalam pengambilan sampel air terdiri dari:

1. Pengukur senyawa Kimia-Fisika seperti DO meter, $\mathrm{pH}$ meter, turbidity meter, Konduktimeter, termometer, pengukur debit.

2. Wadah dan botol gelas untuk sampel pengujian: senyawa organik, logam total dan terlarut, bakteriologi.

3. Bahan pengawet, alat pendingin, stopwatch, buku catatan, dll.
Sedangkan sistem online monitoring kualitas air terdiri dari 3 komponen utama yaitu (1) Master Station atau stasiun pusat (Pusat Data) yang dapat melakukan koordinasi, pemantauan dan pengendalian jarak jauh dalam waktu yang singkat, (2) Remote Terminal Units (RTU's) atau substasiun setempat yang melaksanakan pengumpulan dan pengukuran data kualitas air sungai Ciliwung serta memprosesnya secara langsung, (3) Sistem komunikasi data yang mendukung pendistribusian data antara stasiun pusat dan sub-stasiun melalui GSM (Global System for Mobile Communications) ${ }^{(10)}$.

Sedangkan sub-stasiun yang akan dibangun di sungai Ciliwung terdiri komponen utama, yaitu : smart data logger, sistem kelistrikan dan sistem pengambilan sampling air (sensor).

Kemudian dilengkapi peralatan pendukung seperti tangki penampung, pompa untuk lokasi yang tidak memungkinkan sensor dicelupkan ke sungai, solar cell, dan running text untuk menampilkan nilai parameter kualitas air kepada masyarakat.

\subsection{Metode}

Pengambilan sampel dilakukan berdasarkan metode sampling purposif yaitu tata cara pengambilan sampel berdasarkan adanya pertimbangan. Pertimbangan yang berhubungan dengan lokasi sumber kegiatan yang diduga memberikan beban pencemaran. Pengambilan sampel di daerah hulu didasarkan bahwa daerah hulu belum ada kegiatan yang memberikan beban pencemaran, sedangkan pengambilan sampel di daerah tengah sungai didasarkan pada banyaknya kegiatan yang diduga memberikan kontribusi terjadinya pencemaran di Sungai Ciliwung.

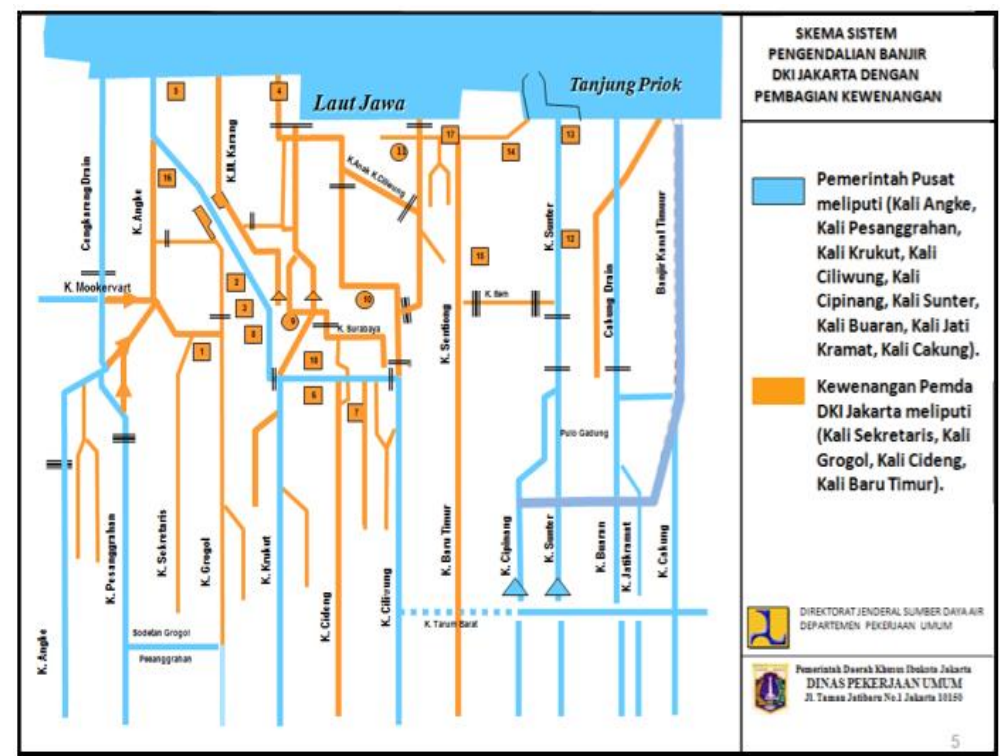

Gambar 2 : Pembagian Kewenangan Pengelolaan Sungai di Wilayah DKI Jakarta 
Survei dilakukan dengan cara mengambil sampel air dan sampel tersebut di analisa di laboratorium Karsa Buana Lestari (KBL), Jakarta. Parameter yang dianalisa yakni temperatur, $\mathrm{pH}$, Zat Padat Terlarut (TDS), total zat padat tersuspensi (TSS), oksigen terlarut (DO), lemak, BOD, COD angka permanganat dan deterjen (MBAS).

\section{HASIL DAN PEMBAHASAN}

Pembahasan dilakukan pada hasil analisa kualitas sampel air Sungai Ciliwung di 9 (sembilan) titik yang telah dilakukan di Laboratorium Karsa Buana lestari (KBL) Jakarta. Hasil analisa kualitas air sungai Ciliwung di tiap titik sampling dapat dilihat pada Tabel 2.

Tabel 1. Lokasi Pengambilan Sampel Air Sungai Ciliwung

\begin{tabular}{|c|c|c|}
\hline No & Nama Lokasi & Lokasi Pengambilan Sampel \\
\hline 1. & Ciliwung - Kelapa Dua & $\begin{array}{l}\text { Jalan Komjen Pol.M. Jasin (Akses UI), Srengeng } \\
\text { Sawah/Pondok Cina - Kelapa Dua. } \\
\text { Latitude: } 6.3545^{\circ} \mathrm{S} \text {, Longitude: } 106.8360^{\circ} \mathrm{E} \text {, Altitude: } 49 \mathrm{~m}\end{array}$ \\
\hline 2. & $\begin{array}{l}\text { Anak Sungai/Saluran JI. RA } \\
\text { Fadilah }\end{array}$ & $\begin{array}{l}\text { Jembatan Jalan RA. Fadillah, (dekat kolam renang), Kelurah } \\
\text { Cijantung, Kecamatan Pasar Rebo } \\
\text { Latitude: } 6.3157^{\circ} \mathrm{S} \text {, Longitude: } 106.8585^{\circ} \mathrm{E} \text {, Altitude: } 50 \mathrm{~m}\end{array}$ \\
\hline 3. & $\begin{array}{l}\text { Ciliwung- Di Bawah TOL } \\
\text { Lingkar Luar Jakarta }\end{array}$ & $\begin{array}{l}\text { Sungai Ciliwung di bawah TOL Lingkar Luar Jakarta. } \\
\text { Jl. Sederhana-Cijantung. } \\
\text { Latitud: } 6.30618^{\circ} \mathrm{S} \text {, Longitude: } 106.8582^{\circ} \mathrm{E} \text {, Altitude: } 11 \mathrm{~m}\end{array}$ \\
\hline 4. & $\begin{array}{l}\text { Ciliwung - Sebelum } \\
\text { Pertemuan Sungai Condet }\end{array}$ & $\begin{array}{l}\text { Jalan Ciliwung, Cililitan, Kramat jati } \\
\text { Latitude: } 6.2627^{\circ} \mathrm{S} \text {, Longitude: } 106.8592^{\circ} \mathrm{E} \text {, Altitude: } 22 \mathrm{~m} \\
\text { Kelurahan : Cililitan, } \\
\text { Kecamatan : Kramat Jati }\end{array}$ \\
\hline 5. & $\begin{array}{l}\text { Sungai Condet Sebelum } \\
\text { Masuk Ciliwung }\end{array}$ & $\begin{array}{l}\text { Sungai Condet sebelum masuk sungai Ciliwung. } \\
\text { Jl. Ciliwung, Cililitan, Kramat Jati. } \\
\text { Latitude: } 6.2628^{\circ} \mathrm{S} \text {, Longitude: } 106.8594^{\circ} \mathrm{E} \text {, Altitude: } 22 \mathrm{~m} \\
\text { Kelurahan : Cililitan, Kecamatan : Kramat Jati }\end{array}$ \\
\hline 6. & Ciliwung - Jembatan Kalibata & $\begin{array}{l}\text { Sungai Ciliwung Sebelum Jembatan Kalibata. } \\
\text { Jl. Pahlawan Kalibata. } \\
\text { Latitude: } 6.2585^{\circ} \mathrm{S} \text {, Longitude: } 106.8604^{\circ} \mathrm{E} \text {, Altitude: } 20 \mathrm{~m} \\
\text { Kelurahan : Cililitan, Kecamatan : Kramat Jati }\end{array}$ \\
\hline 7. & $\begin{array}{l}\text { Ciliwung Setelah Pintu Air } \\
\text { Manggarai Arah Istiqlal }\end{array}$ & $\begin{array}{l}\text { Sungai Ciliwung setelah pintu air manggarai ke arah Istiqlal. } \\
\text { Kelurahan : Pegangsaan, Kecamatan : Menteng. } \\
\text { Latitude : } 6.2077^{\circ} \mathrm{S} \text {, Longitude : } 106.8491^{\circ} \mathrm{E} \text {, Altitude : } 11 \mathrm{~m}\end{array}$ \\
\hline 8. & $\begin{array}{l}\text { Ciliwung Setelah RS Cipto } \\
\text { Mangun Kusumo (RSCM) }\end{array}$ & $\begin{array}{l}\text { Sungai Ciliwung Setelah RS Cipto Mangun Kusumo (RSCM } \\
\text { JI.Inspeksi, Belakang RS Cipto Mangunkusumo } \\
\text { Kelurahan: Kenari, Kecamatan : Senen } \\
\text { Latitude: } 6.19707^{\circ} \mathrm{S} \text {, Longitude: } 106.84547^{\circ} \mathrm{E}_{1} \text { Altitude: } 7 \mathrm{~m}\end{array}$ \\
\hline 9. & Ciliwung- Mesjid Istiqlal & $\begin{array}{l}\text { Ciliwung Jembatan Pintu Selatan Masijd Istiqal. } \\
\text { Latitude: } 6.17140^{\circ} \mathrm{S} \text {, Longitude: } 106.83108^{\circ} \mathrm{E} \text {, Altitude: } 4 \mathrm{~m}\end{array}$ \\
\hline
\end{tabular}

Tabel 2. Kualitas Sungai Ciliwung Segmen Kelapa Dua-Istiqlal

\begin{tabular}{|c|c|c|c|c|c|c|c|c|c|c|c|}
\hline NO & Inisial & $\mathrm{pH}$ & $\begin{array}{c}\text { Organik- } \\
\mathrm{KMnO}_{4} \\
\mathrm{mg} / \mathrm{l}\end{array}$ & $\begin{array}{l}\text { TSS } \\
\mathrm{mg} / \mathrm{l}\end{array}$ & $\begin{array}{c}\text { Amoniak } \\
\mathrm{mg} / \mathrm{l}\end{array}$ & $\begin{array}{c}\text { MBAS } \\
\mathrm{mg} / \mathrm{l}\end{array}$ & $\begin{array}{l}\mathrm{COD} \\
\mathrm{mg} / \mathrm{l}\end{array}$ & $\begin{array}{l}\text { BOD } \\
\mathrm{mg} / \mathrm{l}\end{array}$ & $\begin{array}{l}\mathrm{DO} \\
\mathrm{mg} /\end{array}$ & $\begin{array}{c}\text { Suhu } \\
{ }^{\circ} \mathrm{C}\end{array}$ & $\begin{array}{l}\text { Debit } \\
\mathrm{m}^{3} / \text { det }\end{array}$ \\
\hline 1. & $\begin{array}{l}\text { Ciliwung-Kelapa } \\
\text { Dua }\end{array}$ & 7,1 & 8 & 20 & 0,05 & 0,1 & 27 & 15 & 3,5 & 27,9 & 17,92 \\
\hline 2. & $\begin{array}{l}\text { Anak Sungai - JI. } \\
\text { RA Fadilah }\end{array}$ & 7,4 & 18 & 24 & 0,02 & 0,3 & 45 & 25 & 3,3 & 29,1 & 0,74 \\
\hline 3. & $\begin{array}{l}\text { Ciliwung - } \\
\text { Dibawah } \\
\text { Jembatan lingkar } \\
\text { luar }\end{array}$ & 6,9 & 8 & 32 & 0,05 & 0,1 & 28 & 14 & 3,5 & 29,2 & 24,85 \\
\hline 4. & $\begin{array}{l}\text { Ciliwung - } \\
\text { Sebelum Sungai } \\
\text { Condet } \\
\end{array}$ & 6,9 & 6 & 18 & 0,02 & 0,2 & 23 & 12 & 3,5 & 29,6 & - \\
\hline 5. & Sungai Condet & 7,1 & 21 & 474 & 0,02 & 1 & 57 & 27 & 3,2 & 30,4 & 3,61 \\
\hline 6. & $\begin{array}{l}\text { Ciliwung- } \\
\text { Jembatan } \\
\text { kalibata }\end{array}$ & 6,9 & 10 & 62 & 0,1 & 0,1 & 31 & 19 & 3,4 & 30 & 39,43 \\
\hline 7. & $\begin{array}{l}\text { Ciliwung - } \\
\text { Setelah Pintu Air } \\
\text { Manggarai Arah } \\
\text { Istiqlal }\end{array}$ & 6,6 & 13 & 40 & 0,04 & 0,1 & 34 & 22 & 3,4 & 32,1 & - \\
\hline 8. & $\begin{array}{l}\text { Ciliwung - } \\
\text { Setelah Outlet } \\
\text { RSCM }\end{array}$ & 6,8 & 58 & 166 & 0,3 & 1 & 143 & 77 & 2,8 & 31,6 & - \\
\hline 9. & Ciliwung - Istiqlal & 7,5 & 71 & 276 & 0,4 & 1 & 228 & 126 & 2 & 31,4 & 6,75 \\
\hline
\end{tabular}




\subsection{Parameter pH}

Untuk parameter $\mathrm{pH}$ mulai dari kelapa Dua sampai Istiqlal relatif normal yakni berkisar antara $\mathrm{pH}$ 6,6 sampai dengan $\mathrm{pH} 7,5$. pH di titik Masjid Istiqlal mempunyai nilai yang paling tinggi $(7,5)$ dan yang paling rendah $(6,6)$ di titik setelah pintu air Manggarai (Gambar 4). Kenaikan nilai pH di titik Masjid Istiqlal dapat disebabkan oleh pengaruh limbah laundry dari RS. Cipto Mangunkusumo dan RS. Cikini. Karena larutan deterjen akan menaikkan $\mathrm{pH}$ air serta dapat mengganggu kehidupan organisme dalam air ${ }^{(11)}$.

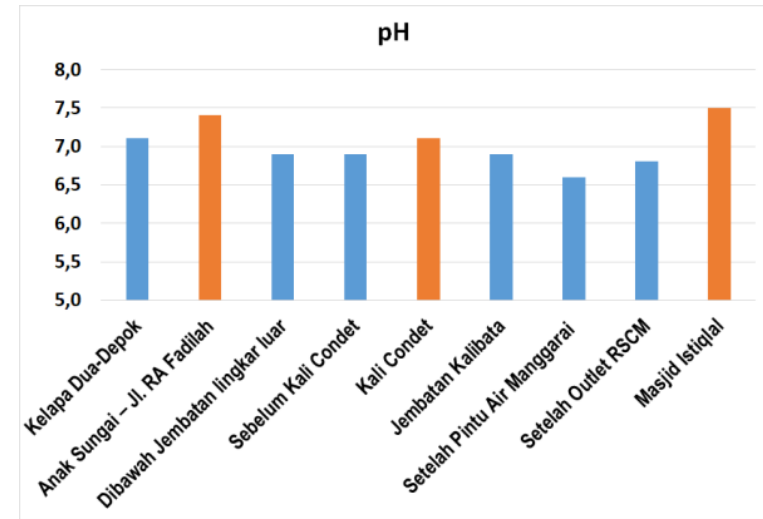

Gambar 4. Hasil Pengukuran pH Air Sungai Ciliwung

\subsection{Parameter Dissolve Oxygen (DO)}

Konsentrasi DO atau oksigen terlarut di titik sampling Kelapa Dua adalah $3,5 \mathrm{mg} / \mathrm{l}$. Nilai ini relatif lebih rendah jika dibandingkan dengan standar peruntukan air sungai kelas I untuk peruntukan air baku air minum yakni $6 \mathrm{mg} / \mathrm{I}^{(6)}$. Konsentrasi DO sungai Ciliwung semakin ke arah hilir semakin kecil, ini terlihat di titik sampling Istiqlal, konsentrasi DO menjadi 2 mg/l (Gambar 5). Hal ini karena konsentrasi DO menurun drastis pada saat beban pencemar yang masuk ke perairan ${ }^{(12)}$.

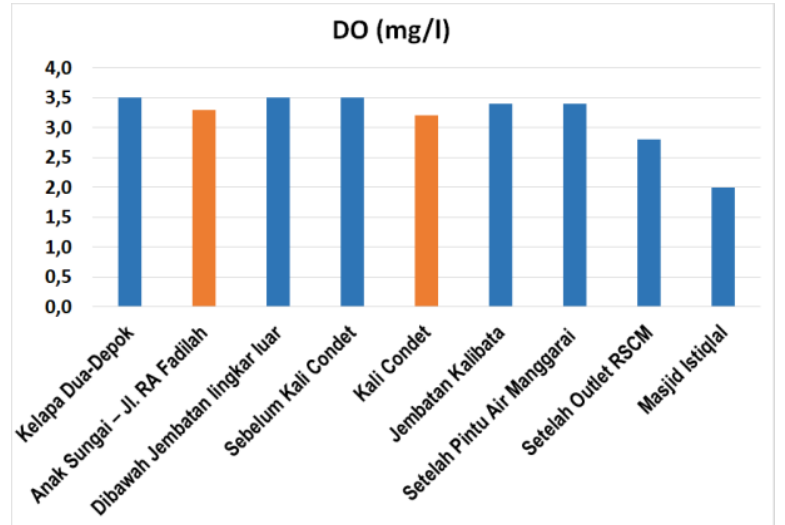

Gambar 5. Hasil Pengukuran DO Air
Hal ini menunjukan indikasi tingkat pencemaran sungai Ciliwung ke arah hilir yang semakin tinggi. Dengan konsentrasi DO sebesar $2 \mathrm{mg} / \mathrm{l}$ maka air sungai sudah mendekati kondisi anaerob. Jika kondisi air sungai dalam keadaan anaerob maka akan terjadi penguraian secara anaerobik yaitu zat organik akan terurai menjadi $\mathrm{CO}_{2}$ dan gas metan, sedangkan senyawa nitrogen akan menjadi amoniak, sedangkan senyawa sulfur akan diubah menjadi asam sulfida $\left(\mathrm{H}_{2} \mathrm{~S}\right)$, sehingga air akan menjadi berwarna hitam dan bau.

\subsection{Parameter Total Suspended Solid (TSS)}

Parameter TSS atau padatan tersuspensi di titik sampling Kelapa Dua sebesar $20 \mathrm{mg} / \mathrm{l}$ dan semakin ke arah hilir semakin tinggi (Gambar 6). Konsentrasi TSS kali Condet yang masuk ke sungai Ciliwung sangat tinggi yakni $474 \mathrm{mg} / \mathrm{l}$. Kali Condet merupakan anak sungai Ciliwung yang dikelilingi oleh permukiman padat, pasar dan industri kecilmenengah. Bahan-bahan organik yang merupakan zat tersuspensi terdiri dari berbagai jenis senyawa seperti selulosa, lemak, protein yang melayanglayang dalam air atau dapat juga berupa mikroorganisme seperti bakteri, algae, dan sebagainya. Bahan-bahan organik ini selain berasal dari sumber-sumber alamiah juga berasal dari buangan kegiatan manusia seperti kegiatan industri, pertanian, pertambangan atau kegiatan rumah tangga ${ }^{(13)}$.

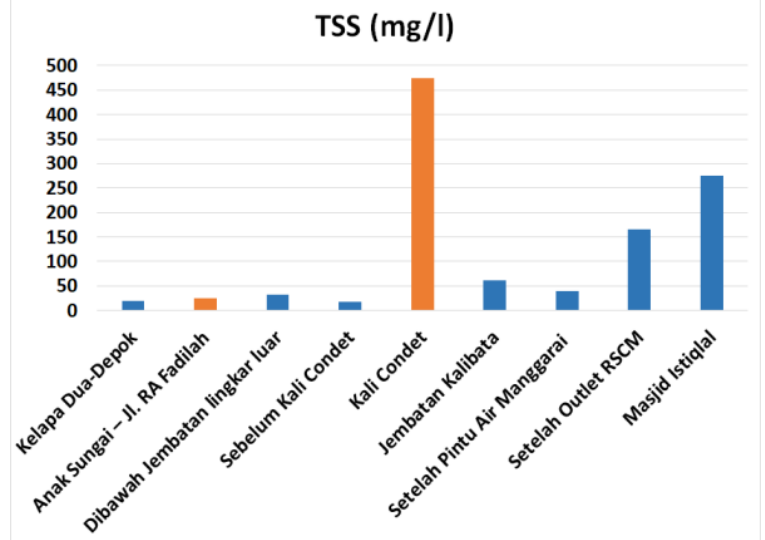

Gambar 6. Hasil Pengukuran TSS Air Sungai Ciliwung

Di titik sampling Jembatan Kalibata konsentrasi TSS $62 \mathrm{mg} / \mathrm{l}$. hal ini disebabkan karena pengaruh masuknya air kali Condet yang konsentrasi TSS nya cukup tinggi. Di titik sampling Manggarai setelah pintu air yang mengarah ke Istiqlal, konsentrasi TSS adalah $40 \mathrm{mg} / \mathrm{l}$. Hal ini kemungkinan disebabkan karena kecepatan aliran setelah melalui pintu air lebih rendah sehingga konsentrasi TSS nya lebih rendah dibandingkan dengan TSS di titik sampling Jembatan Kalibata. Di titik sampling Masjid Istiqlal konsentrasi TSS naik 
menjadi $276 \mathrm{mg} / \mathrm{l}$. Hal ini disebabkan karena aktivitas pengerukan sedimen sungai Ciliwung di belakang R.S. Cipto Mangun Kusumo. TSS terdiri dari lumpur dan pasir halus serta jasad renik, yang terutama disebabkan oleh kikisan tanah atau erosi yang terbawa ke badan air ${ }^{(14)}$.

\subsection{Parameter Amoniak $\left(\mathrm{NH}_{4}\right)$}

Konsentrasi Amoniak $\left(\mathrm{NH}_{4}\right)$ di titik sampling Kelapa Dua adalah 0,05 mg/l dan di titik sampling sebelum kali Condet sedikit turun menjadi $0,02 \mathrm{mg} / \mathrm{l}$ dan setelah itu semakin ke arah hilir menjadi semakin tinggi. Di titik sampling Istiqlal konsentrasi amoniak menjadi $0,4 \mathrm{mg} / \mathrm{l}$. Kenaikan konsentrasi amoniak yang sangat tajam terjadi di arah hilir sungai Ciliwung yaitu segmen Manggarai-Istiqlal (Gambar 7). Kenaikan konsentrasi amoniak ini disebabkan karena semua lokasi yang dilewati berada di area yang kepadatan penduduknya lebih tinggi daripada area lainnya ${ }^{(13)}$. Kadar amonia yang tinggi mengindikasikan adanya pencemaran bahan organik dari limbah domestik ${ }^{(15)}$. Secara fisik terlihat bahwa semakin ke utara air sungai Ciliwung berwarna hitam dan tercium bau semakin menyengat.

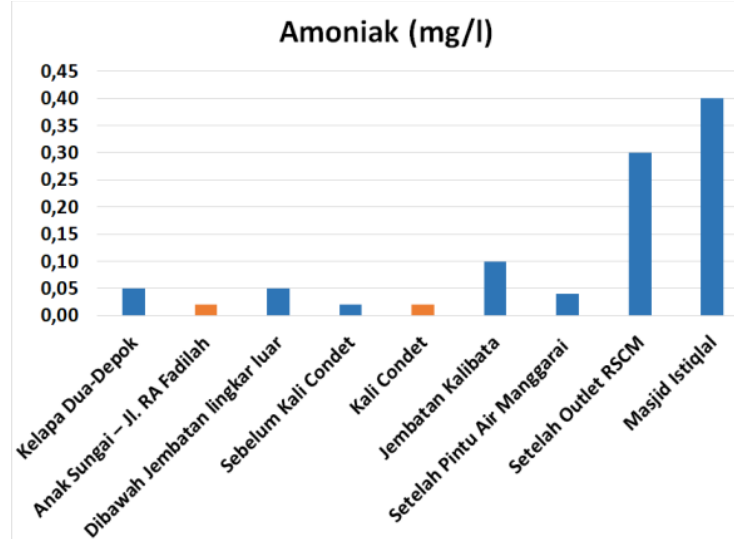

Gambar 7. Hasil Pengukuran Amoniak $\left(\mathrm{NH}_{4}\right)$ Air Sungai Ciliwung

\subsection{Parameter Deterjen (MBAS)}

Untuk parameter deterjen (MBAS) konsentrasi yang tinggi terdapat di titik sampling anak sungai di JI. Fadilah, sungai Condet, titik sampling setelah R.S. Cipto Mangunkusumo (RSCM) dan titik sampling Istiqlal.

Dititik sampling setelah oulet RSCM dan Istiqlal konsentrasi deterjen (MBAS) 1,0 mg/l (Gambar 8). $\mathrm{Hal}$ ini diindikasikan pencemaran limbah tidak hanya domestik tetapi juga limbah dari kegiatan rumah sakit seperti air bekas pencucian pakaian, cucian luka, cucian darah dan lainnya ${ }^{(16)}$. Deterjen sangat berbahaya bagi lingkungan karena dari beberapa kajian menyebutkan bahwa deterjen memiliki kemampuan untuk melarutkan bahan bersifat karsinogen, misalnya Benzonpyrene, selain gangguan terhadap masalah kesehatan, kandungan deterjen dalam air minum akan menimbulkan bau dan rasa tidak enak.

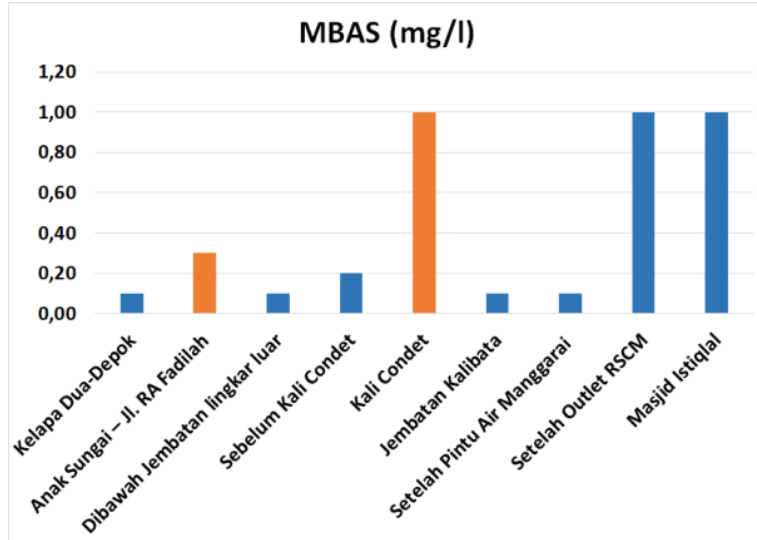

Gambar 8. Hasil Pengukuran Deterjen (MBAS) Air Sungai Ciliwung

\subsection{Parameter Organik}

Untuk parameter zat organik $\left(\mathrm{KMnO}_{4}, \mathrm{COD}\right.$ dan BOD) menunjukkan kecenderungan yang hampir sama. Di titik sampling Kelapa Dua, konsentrasi COD sebesar $27 \mathrm{mg} / \mathrm{l}$ dan konsentrasi BOD sebesar $15 \mathrm{mg} / \mathrm{l}$. Hal ini sudah melebihi standar baku mutu peruntukkan air Golongan $B^{(6)}$ atau standar Baku Mutu air kelas 1 untuk peruntukkan air baku air minum. Hal ini menunjukkan bahwa sungai Ciliwung yang memasuki wilayah DKI Jakarta sudah tercemar akibat aktivitas di wilayah hulu (Depok dan Bogor) ${ }^{(2)}$.

Di titik sampling sebelum sungai Condet konsentrasi zat organik sedikit lebih rendah dibandingkan dengan konsentrasi zat organik di titik sampling Kelapa Dua, meskipun sudah tercampur dengan anak sungai JI. RA Fadilah yang konsentrasi zat organiknya cukup tinggi. Hal ini menunjukkan indikasi bahwa sungai Ciliwung pada segmen Kelapa Dua sampai dengan sebelum pertemuan dengan sungai Condet, masih terjadi pemurnian alami (self purification). Di titik sampling sungai Condet sebelum masuk ke sungai Ciliwung, konsentrasi zat organik cukup tinggi yakni zat organik $\left(\mathrm{KMnO}_{4}\right) 21 \mathrm{mg} / \mathrm{l}, \mathrm{COD} 57 \mathrm{mg} / \mathrm{l}$ dan BOD $27 \mathrm{mg} / \mathrm{l}$. Sungai Condet termasuk anak sungai yang sangat berpotensi mencemari sungai Ciliwung karena sudah tercemar oleh air limbah domestik maupun industri.

Setelah pertemuan dengan sungai Condet, konsentrasi zat organik di sungai Ciliwung terus meningkat dan pada segmen Manggarai sampai dengan Istiqlal konsentrasi zat organik meningkat dengan tajam (Gambar 9,10,11). Hal ini disebabkan jumlah penduduk dan kepadatan di sekitar sungai Condet (Kec. Kramat Jati) cukup tinggi( ${ }^{(17)}$, sehingga merupakan penyumbang kadar bahan organik dari limbah domestiknya ${ }^{(14)}$. Di titik sampling Manggarai, 
konsentrasi COD $34 \mathrm{mg} / \mathrm{l}$ dan konsentrasi BOD 22 $\mathrm{mg} / \mathrm{l}$. Setelah sampai di titik sampling Istiqlal konsentrasi COD $228 \mathrm{mg} / \mathrm{l}$ dan konsentrasi BOD $126 \mathrm{mg} / \mathrm{l}$. Hal ini menunjukkan bahwa pada segmen Manggarai sampai dengan Istiqlal beban pencemaran organik meningkat sangat tajam.

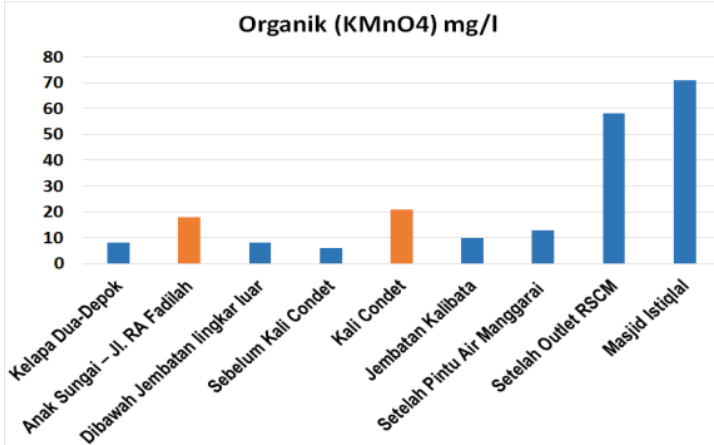

Gambar 9. Hasil Pengukuran Organik $\left(\mathrm{KMnO}_{4}\right)$ Air Sungai Ciliwung

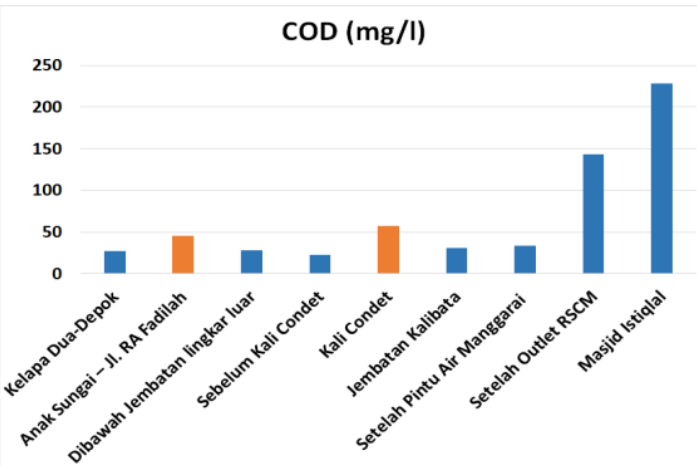

Gambar 10. Hasil Pengukuran Organik (COD) Air Sungai Ciliwung

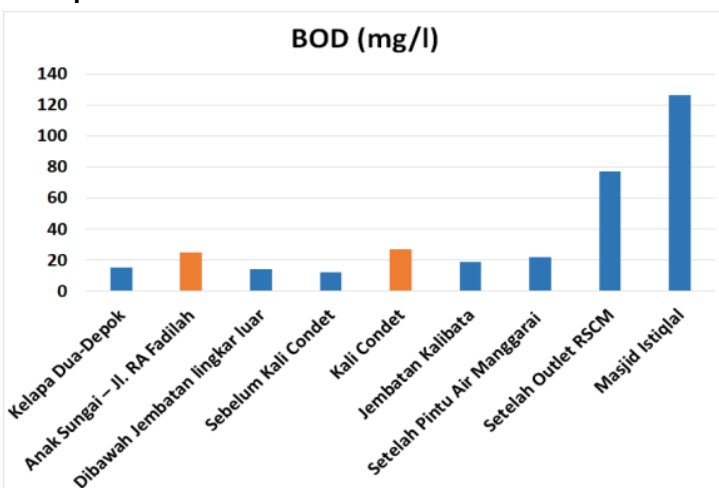

Gambar 11. Hasil Pengukuran Organik (BOD) Air Sungai Ciliwung

\subsection{Pengukuran Debit Sungai}

Selain parameter kimia dilakukan pula pengukuran debit sungai di beberapa titik sampling. Debit sungai Ciliwung di titik sampling Kelapa Dua $17,92 \mathrm{~m}^{3} /$ detik, setelah sampai di titik sampling Jembatan Kalibata debit sungai meningkat menjadi $39,43 \mathrm{~m}^{3} /$ detik, hal ini disebabkan kecepatan aliran disini cukup tinggi karena badan sungai lurus sepanjang $\pm 500 \mathrm{~m}$. Sedangkan di titik sampling Istiqlal debit sungai Ciliwung $6,75 \mathrm{~m}^{3} /$ detik (Gambar 12). Pada titik-titik yang mempunyai nilai debit airnya rendah cenderung tercemar. Semakin tinggi debit maka kadar organik (sebagai BOD dan COD) semakin kecil yang disebabkan oleh proses pengenceran ${ }^{(18)}$.

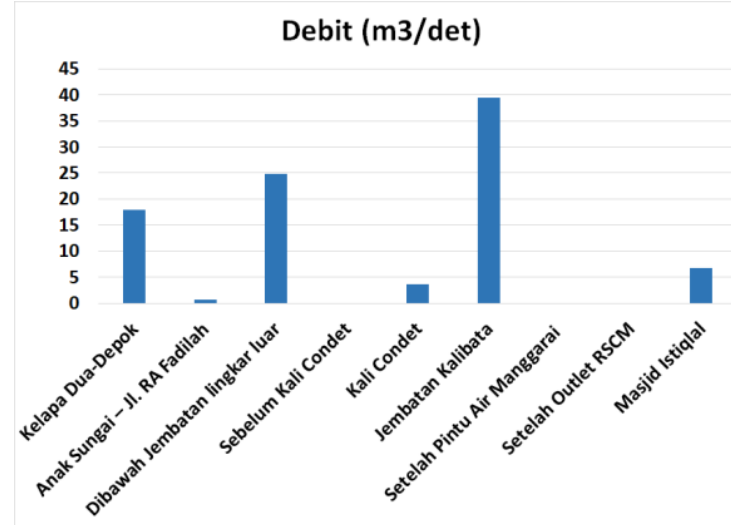

Gambar 12. Hasil Pengukuran Debit Air Sungai Ciliwung

\subsection{Perhitungan Beban Pencemaran}

Dari hasil analisa kualitas air dan pengukuran debit air sungai dapat dihitung beban pencemaran yang masuk ke sungai Ciliwung. Untuk perhitungan beban pencemaran diambil parameter yang signifikan (parameter kunci) yakni parameter COD. Beban organik (COD) dihitung dengan rumus: Debit dikalikan dengan Konsentrasi COD. Hasil perhitungan Beban Organik (COD) dapat dilihat Pada Gambar 13.

Dari hasil perhitungan tersebut $(\mathrm{BPM}=$ Debit $\mathrm{X}$ Unsur Pencemar) dapat diketahui beban organik (COD) di titik sampling Kelapa Dua adalah 483,84 gram COD perdetik, beban organik di titik sampling Jembatan Kalibata 1.237,83 gram COD per detik, dan sampai di Pintu Air Manggarai beban organik meningkat menjadi 1.360 gram COD per detik. Dengan demikian dapat dilihat bahwa penambahan beban organik dari segmen Kelapa Dua sampai Jembatan Kalibata adalah 753,99 gram COD per detik atau $65.144,736 \mathrm{~kg}$ COD per hari. Nilai ini dihitung hanya sesaat dan akan berfluktuasi bergantung kepada besar kecilnya sumber pencemaran.

Sedangkan penambahan beban organik di segmen Jembatan Kalibata sampai dengan Manggarai adalah 122,17 gram COD per detik atau $10.555,5 \mathrm{~kg}$ COD per hari. Jika dihitung dari Kelapa Dua sampai dengan Manggarai, maka penambahan beban organik (COD) adalah 876,16 gram COD per detik atau $75.700,22 \mathrm{~kg}$ COD per hari. 


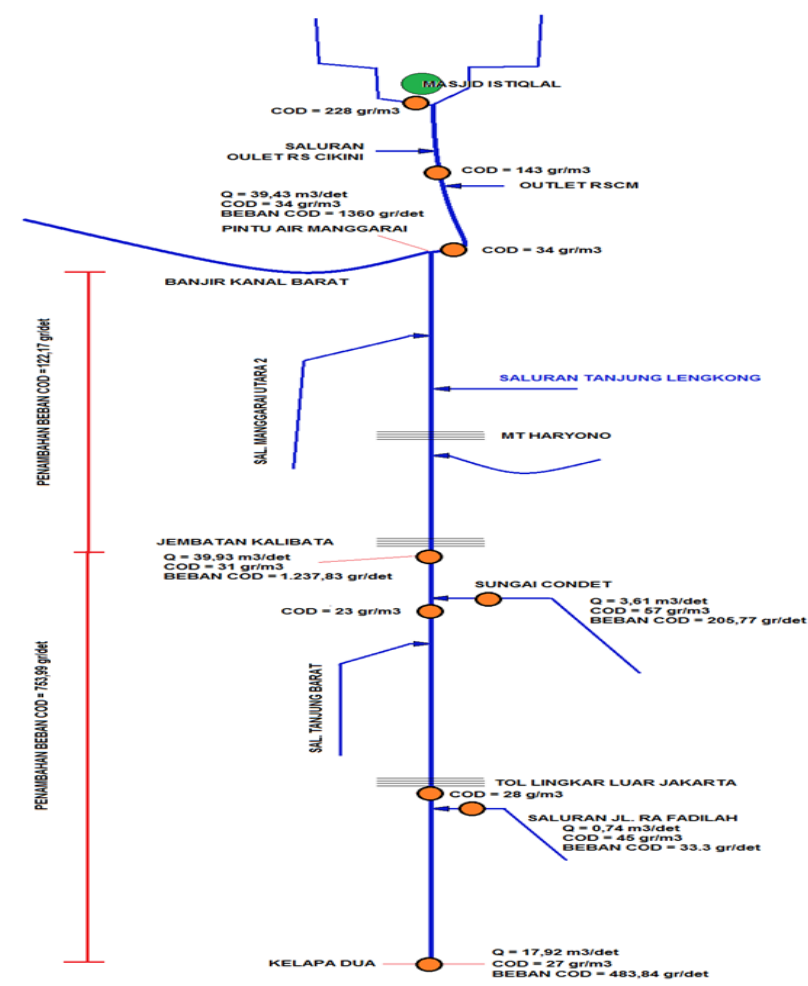

Gambar 13. Hasil Perhitungan Beban Organik (COD) Air Sungai Ciliwung

Jika diasumsikan beban COD per kapita 40 gram COD per hari ${ }^{(9)}$ maka beban organik yang masuk sungai Ciliwung segmen Kelapa Dua sampai dengan Manggarai setara dengan beban organik yang dikeluarkan oleh penduduk sebesar 1.892 .505 orang.

Untuk segmen Manggarai sampai dengan Istiqlal peningkatan konsentrasi COD sangat besar. Hal ini disebabkan karena debit sungai kecil yakni sekitar $6,75 \mathrm{~m}^{3} /$ detik dan air limbah dari kegiatan domestik, perkantoran dan komersial cukup banyak. Jika dihitung maka perkiraan beban pencemar yang masuk ke sungai Ciliwung segmen Manggarai -Istiqlal adalah $=6,75 \mathrm{~m}^{3} /$ detik $\times(228$ 34) $\mathrm{gr} / \mathrm{m}^{3}=1.309,5 \mathrm{gr}$ COD $/$ detik $=113.140,8 \mathrm{~kg}$ $\mathrm{COD} /$ hari atau setara dengan beban organik yang dikeluarkan oleh penduduk sebesar 4.525.632 orang.

\subsection{Online monitoring Kualitas Air Sungai}

Dalam melakukan pemantauan kualitas air sungai, cara konvensional yang saat ini dilakukan adalah mengambil sampel di lokasi pemantauan, membawa ke laboratorium dan menganalisakannya. Beberapa kendala yang dihadapi terkait pemantauan rutin kualitas air sungai secara konvensional ini, diantaranya adalah jarak dari lokasi ke laboratorium analisa kualitas air yang cukup jauh, kemacetan lalu lintas, dan juga resiko bahaya saat pengambilan sampel langsung di lokasi sungai. Kendala lain yang cukup signifikan yakni biaya analisa sampel yang cukup mahal sehingga untuk melakukan pemantauan rutin di banyak titik di aliran sungai, diperlukan anggaran yang besar.

Upaya yang dilakukan untuk mengatasi kendala tersebut di atas dan mengefisienkan pemantauan kualitas air sungai adalah dengan menerapkan sistem online monitoring (OnLimo) kualitas air di beberapa lokasi pemantauan baik di lokasi sumber pencemar, maupun di lokasi aliran sungai itu sendiri. Pusat Teknologi Lingkungan, BPPT telah mengembangkan sistem pemantauan kualitas air secara online dan bekerjasama dengan Kementerian Lingkungan Hidup dan Kehutanan (KLHK) untuk melakukan penerapan online monitoring kualitas air di beberapa lokasi pemantauan di aliran sungai Ciliwung maupun di sumber air limbah (industri, rumah sakit, dll).

\section{KESIMPULAN}

Beberapa kesimpulan diperoleh dari hasil kegiatan di atas menunjukkan bahwa di sungai Ciliwung semakin ke arah hilir terjadi pencemaran semakin berat. Untuk memantau secara cepat kondisi kualitas air sungai Ciliwung telah di rekomendasikan untuk dipasang sensor online monitoring di 7 (tujuh) titik pantau mulai dari Kelapa Dua sampai Masjid Istiqlal. Karena keterbatasan dana, maka saat ini baru dibangun 3 (tiga) stasiun pemantauan kualitas air secara online yaitu di Kelapa Dua, Depok mewakili hulu, di Pintu Air Manggarai mewakili tengah dan di jembatan Masjid Istiqlal mewakili hilir sungai Ciliwung. 


\section{PERSANTUNAN}

Penulis menyampaikan ucapan terima kasih kepada Direktorat Pengendalian Pencemaran Air, Ditjen PPKL, KLHK yang telah berkerjasama dengan Pusat Teknologi Lingkungan (PTL), TPSA, BPPT dalam mendukung dan mendanai kegiatan ini. Terima kasih juga disampaikan kepada rekanrekan Tim Simulasi Model, PTL, TPSA, BPPT yang telah menerapkan teknologi Online monitoring kualitas air sungai Ciliwung.

\section{DAFTAR PUSTAKA}

1. Anonimous. (2012). Laporan Status Lingkungan Hidup Daerah Provinsi DKI Jakarta Tahun 2011, BPLHD Provinsi DKI Jakarta, II-136.

2. Yudo. S. (2010). Kondisi Kualitas Air Sungai Ciliwung di Wilayah Dki Jakarta Ditinjau Paramater Organik, Amoniak, Fosfat, Deterjen dan Bakteri Coli. JAI Vol. 6. No. 1, PTL-BPPT, 34-42.

3. Anonimous. (2013). Sungai Ciliwung Kini.. Available from https://www.ui.c.id/berita/ \%20sungai-ciliwung-kini-2.html

4. Anonimous. (2005). Publikasi Pengelolaan Kualitas Air Sungai Ciliwung. Deputi Bidang Peningkatan Konservasi Sumber Daya.

5. Alam dan Pengendalian Kerusakan Lingkungan. Available from: http://www.menlh.go.id/publikasi-pengelolaankualitas-air-sungai-ciliwung/

6. Moersidik, Widhiasari R. (2015). Load Capacity Study of Ciliwung Watershed. Center for Research of Human Resource and The Environment University of Indonesia.

7. Anonimous. (1995). Keputusan Gubernur DKI Jakarta Nomor 582 tahun 1995 tentang Penetapan Peruntukan dan Baku Mutu Air Sungai/Badan Air Serta Baku Limbah Cair di Wilayah Daerah Khusus Ibukota Jakarta.

8. Anonimous. (2014). Laporan Akhir Pengkajian Penerapan Sistem Monitoring Pengendalian Pencemaran DAS Ciliwung. Pusyantek-BPPT.

9. Wahjono, H.D, et all, (2015). Buku Sistem Pemantauan Online Untuk Pengendalian Pencemaran Kualitas Air Sungai di DAS Ciliwung. PTL, BPPT.
10.Wahjono, H.D, et all. (2016). Laporan Akhir Pemasangan Alat Monitoring Online Sistem di Ciliwung (1 Titik), di Cisadane (2 Titik), Di Serayu (2 Titik), dan di Bengawan Solo (2 Titik). Pusyantek-BPPT.

11.Yudo, S. (2015). Perancangan Basis Data Sistem Online monitoring Multi-Site Kualitas Air Sungai. Prosiding Seminar Nasional Inovasi Teknologi Lingkungan dalam Aksi Gerakan Nasional Indonesia Bersih. BPPT.

12.Ardiyanto, P. Yuantari, M. (2016). Analisis Limbah Laundry Informal dengan Tingkat Pencemaran Lingkungan di Kelurahan Muktiharjo Kidul Kecamatan Pedurungan Semarang. Jukung Jurnal Teknik Lingkungan. Unlam.

13.Budiman, A. (2010). Pemodelan Kualitas Air Dengan Parameter BOD dan DO pada Sungai Ciliwung. Jurnal Teknologi Lingkungan, Vol. 5, No. 3 Juni 2010.

14. Huda, Thorikul. (2009). Hubungan Antara Total Suspended Solid Dengan Turbidity dan Dissolved Oxygen. Available from: http://thorik.staff.uii.ac.id/2009/08/23/hubungan -antara-total-suspendedsolid-dengan-turbiditydan-dissolved-oxygen/.

15.Suryati, T., Rahayu, T., et.al. (2015). Status Kualitas Air DAS Ciliwung Ditinjau dari Parameter Kimia Fisika. Buku Bunga Rampai Aplikasi Teknologi Pengolahan Sumberdaya Air. PTL, BPPT.

16.Effendi, H. (2003). Buku Telaah Kualitas Air: Bagi Pengelolaan Sumber Daya dan Lingkungan Perairan. Kanisius, Yogyakarta.

17.Idaman, N.S., Ineza, (2002). Buku Uji Performance Pengolahan Air Limbah Rumah Sakit dengan Proses Biofilter Tercelup. BPPT.

18.Anonimous. (1995). Jumlah Penduduk Menurut Jenis Kelamin dan Kecamatan 2014. BPS Kota Jakarta Timur. Available from : https://jaktimkota.bps.go.id/dynamictable/2015/ 12/29/3/jumlah-penduduk-menurut-jeniskelamin-dan-kecamatan-2014.html.

19.Irianto, W.E., Machbub, B. (2003). Fenomena Hubungan Debit Air dan Kadar Zat Pencemar dalam Air Sungai (Studi Kasus: Subdps Citarum Hulu. JLP. Vol. 17. No. 52. 